\title{
Changing Roles of Traditional Small Urban Green Spaces (Telajakan) in Bali, Indonesia
}

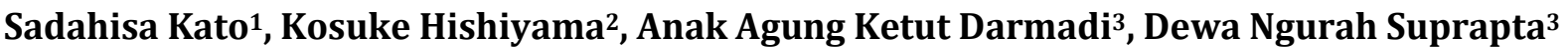 \\ ${ }^{1}$ Institute for Global Human Resource Development, Okayama University, Okayama, Japan \\ ${ }^{2}$ Faculty of Applied Sociology, Kindai University, Osaka, Japan \\ ${ }^{3}$ Laboratory of Biopesticide, Faculty of Agriculture, Udayana University, Denpasar, Indonesia \\ Email: skato1314@gmail.com
}

How to cite this paper: Kato, S., Hishiyama, K., Darmadi, A.A.K. and Suprapta, D.N. (2017) Changing Roles of Traditional Small Urban Green Spaces (Telajakan) in Bali, Indonesia. Open Journal of Ecology, 7, 1-11. http://dx.doi.org/10.4236/oje.2017.71001

Received: November 30, 2016

Accepted: January 13, 2017

Published: January 16, 2017

Copyright $\odot 2017$ by authors and Scientific Research Publishing Inc. This work is licensed under the Creative Commons Attribution International License (CC BY 4.0).

http://creativecommons.org/licenses/by/4.0/

c) (i) Open Access

\begin{abstract}
Bali Island, Indonesia is undergoing rapid land use changes due to heavy development pressure and its fast growing urban population. One such urbanization phenomenon is the shrinkage, deterioration, and disappearance of traditional small urban green spaces in Denpasar, Bali. Focusing on telajakan, a strip of traditional green space between the wall of a housing compound and a ditch/pedestrian path in a roadside, the study aims 1) to investigate and document the changes that are occurring with regards to telajakan and 2) to assess the functions (roles) of telajakan in Denpasar. The research methods include vegetation assessment at a lot scale and in-depth homeowner and village leader interviews with the help of local experts. The results show that telajakan space is often paved over to give way to more front space for the property owner and to ease maintenance. It is also minimized or destroyed as the owner builds a more "western" style house. Traditionally telajakan has multiple functions such as provision of plant and flower materials for Balinese daily rituals, regulation of stormwater from the property, and offering semi-public space for street vendors and neighbours. However, the results show that: diversity of planted species is decreasing; only a couple of functions such as aesthetics and economics are strongly favored; and the semi-public nature of telajakan is being lost. Since telajakan is as much traditional green open space as part of the aesthetics of the Balinese architecture, its loss, minimization, and degradation lead to the loss of Balinese culture and identity. On the other hand, new meaning is given to telajakan's functions such as neighborhood beautification and exhibition of the owner's pride in the modern context. Therefore, policy recommendations to conserve telajakan in the changing urban fabric need to balance these changing needs of telajakan for its use and conservation of traditional rituals and culture of Bali.
\end{abstract}

\section{Keywords}

Telajakan, Bali, Urban Green Spaces 


\section{Introduction}

The island of Bali, Indonesia, a popular tourist destination, is undergoing rapid land use changes due to heavy development pressure and its fast growing urban population. Consequent urban environmental problems are typical but many such as the loss and shrinkage of green spaces, conversion of green spaces to urban uses, urban flooding, illegal garbage disposal, and poor sanitation.

One such urbanization phenomenon is the shrinkage, deterioration, and disappearance of traditional small urban green spaces in Denpasar, Bali. We have focused on telajakan, a strip of traditional green space between the wall of a housing compound and a ditch/pedestrian path in a roadside (Figure 1). The width of telajakan is determined by Balinese traditional architecture, which case between 1.0 and 2.2 meters, and by Bali Regulation No. 10/1999, which case between 0.5 and 2.0 meters [1]. Traditionally telajakan has multiple functions such as provision of plant and flower materials for Balinese daily rituals, regulation of stormwater from the property, and offering semi-public space for street vendors and neighbors. The meaning, concept, and functions of telajakan in the context of traditional open space are elaborated in Yudantini [1].

Lately, as Denpasar undergoes rapid urbanization, telajakan itself and the functions of the plantings in telajakan are changing as well. However, because telajakan has always been part of traditional southern Balinese architecture, local people pay little attention to the changes that are occurring and few scientific studies have been conducted on telajakan. Therefore, two research objectives are first to investigate and document the changes that are occurring with regards to telajakan and second to assess the functions (roles) of telajakan in Denpasar, Bali.

\section{Previous Studies}

The significance of this study is that first, any ecological analysis of telajakan is close to non-existent; no data is available or has been published (at least in

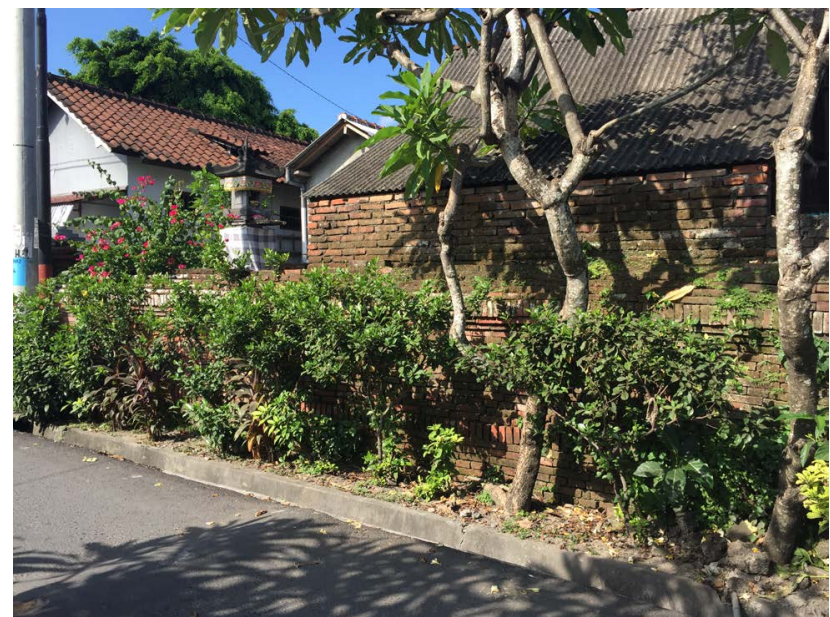

Figure 1. An example of telajakan. 
English). There are, however, some preceding studies on urban green spaces in Bali. Cultural and historical studies of telajakan do exist, including Yudantini (2012) whom argues that telajakan has helped form the identity of the Balinese on the traditional village landscape in Bali [1]. Putra et al. (2013) illustrate the transformation of the traditional Balinese house for tourist facilities, and documented the process of marketization and re-embedding of the traditional elements adjusted for the modern context [2]. Brata (2014) examined the process of commodification of telajakan in Ubud Village, concluding that the telajakan's value as traditional green open space is neglected, resulting in ecological damage and the extinction of the aesthetics of the Balinese architecture, and witnessing the destruction of the Balinese identity [3].

With regards to the functions of telajakan, literature review shows that the primary functions of the plants in telajakan are religious and economic [1]. Plants are used for religious ceremonies, medicinal purposes, spice, aesthetics, and micro economy [4]. Telajakan provides a space to place the penjor during traditional ceremonies [1]. Dwijendra (2008) documents a semi-public nature of telajakan though every telajakan is owned, provided, and maintained by the household [5]. Telajakan used to provide a place for communication with neighbours, and used to be a place for street vendors and wagon stops [5]. Telajakan also provides for stormwater management, onsite infiltration, runoff control, and involves some evapotranspiration with vegetation.

\section{Methods}

In early May, 2016, the authors discussed the idea and framework of the research with Dr. Ngakan Ketut Acwin Dwijendra of STD (Sekolah Tinggi Desain) Bali, an expert of telajakan from the viewpoint of traditional Balinese architecture. Dr. Acwin suggested that the authors observe a couple of areas in Denpasar where he believes that telajakan is still intact. As some authors drove to the suggested areas in search of good examples of remaining telajakan, they stumbled into an area where, based on their expert opinion, apparently a traditional telajakan remains. There they observed the telajakan, took photos, and interviewed the owner about the plantings, use, and maintenance of the telajakan. This is sample 1 (in Village $\mathrm{X}$ in northern Denpasar).

During the interview, new information about local government's telajakan competition was obtained. The owner said that there is a street (in another village) nearby which has won the competition. He thought that the telajakan of the street was a better example of "good" telajakan. After the interview, the authors looked for this street, and found it. The authors then took photos of the telajakan on both sides of the street, interviewed the owner who appeared to have the most well-maintained telajakan with bonsai trees. This is sample 2.

In late August, 2016, some authors returned to sample 1 and this time identified the vegetation species planted and recorded the number of different species. They also measured the width of the telajakan. Afterwards, authors did the same to sample 2. This time, they also identified the planted species and measured the 
width of some other telajakan on the street. These telajakan are sample 3 - 5 . Samples $2-5$ are in Village $C$ in northern Denpasar. The authors also interviewed the village leader and asked about the competition and how they maintain telajakan. They also interviewed a member of vegetable farmers group and the owner of sample 2 again, and asked about the species selection, way of maintenance, whether or not he knows about the competition, etc. The authors used Keng [6] and Periplus Editions [7] as references for identifying the vegetation species and their functions. All the telajakan samples in this study are located in the housing in the villages.

\section{Results}

There are four major results. First, for all five samples, aesthetics, economics, rituals, and canopy (shade) are the four most important functions which the planted species have (Figures 2-6). Especially, aesthetic function is provided by almost $100 \%$ of the planted species. Economic function is the second most

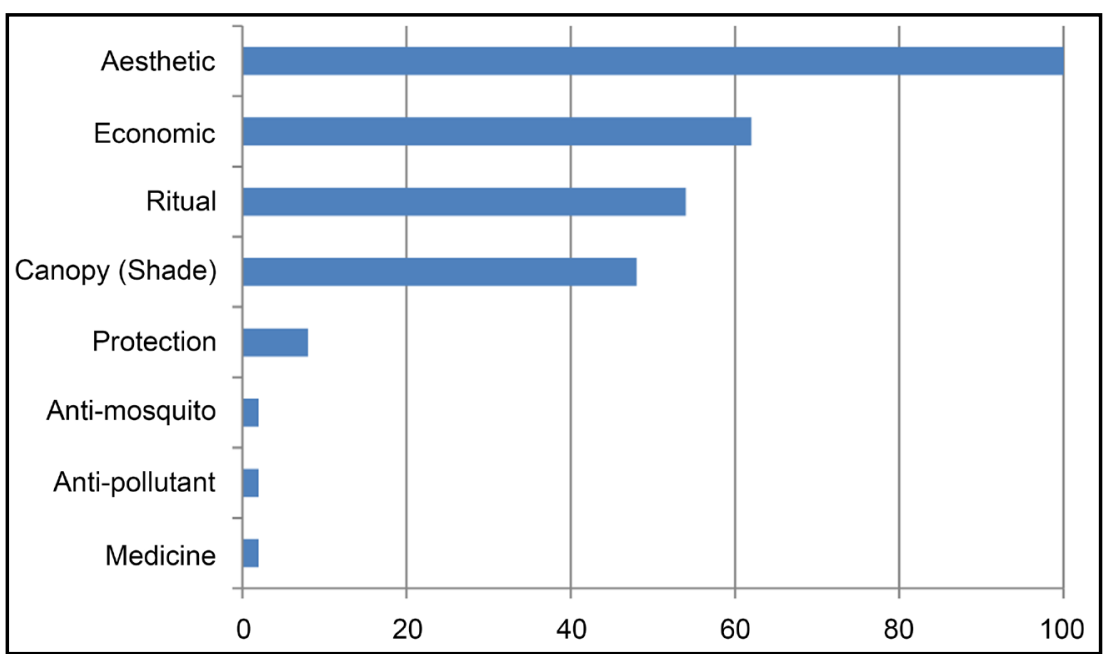

Figure 2. Percentage of the functions provided by the plants in sample 1 .

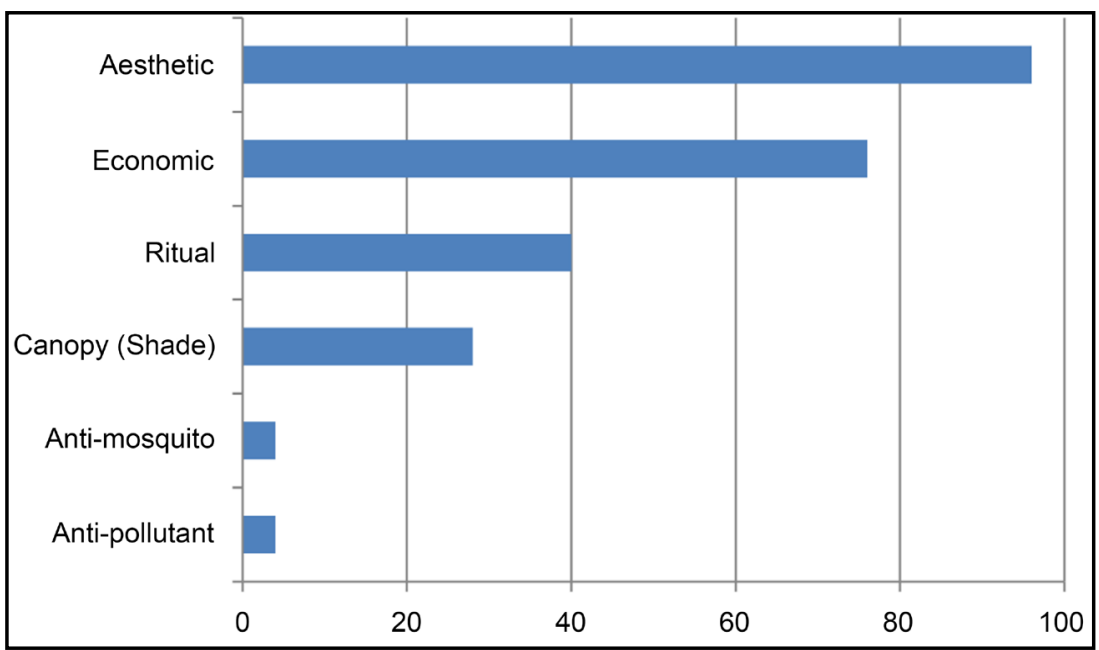

Figure 3. Percentage of the functions provided by the plants in sample 2 . 


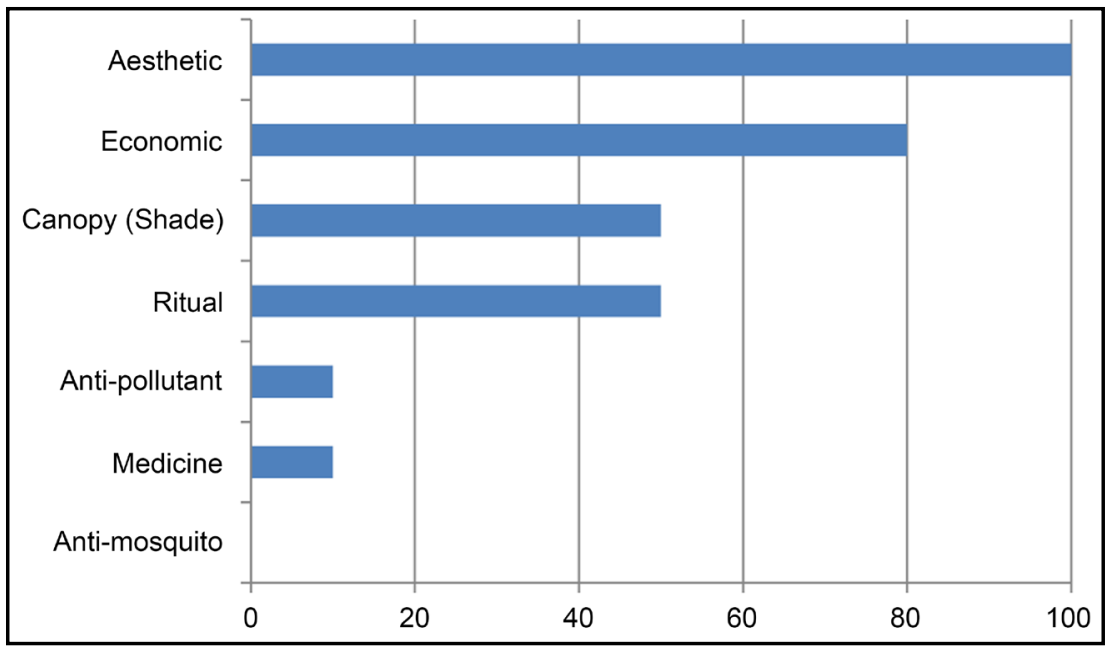

Figure 4. Percentage of the functions provided by the plants in sample 3.

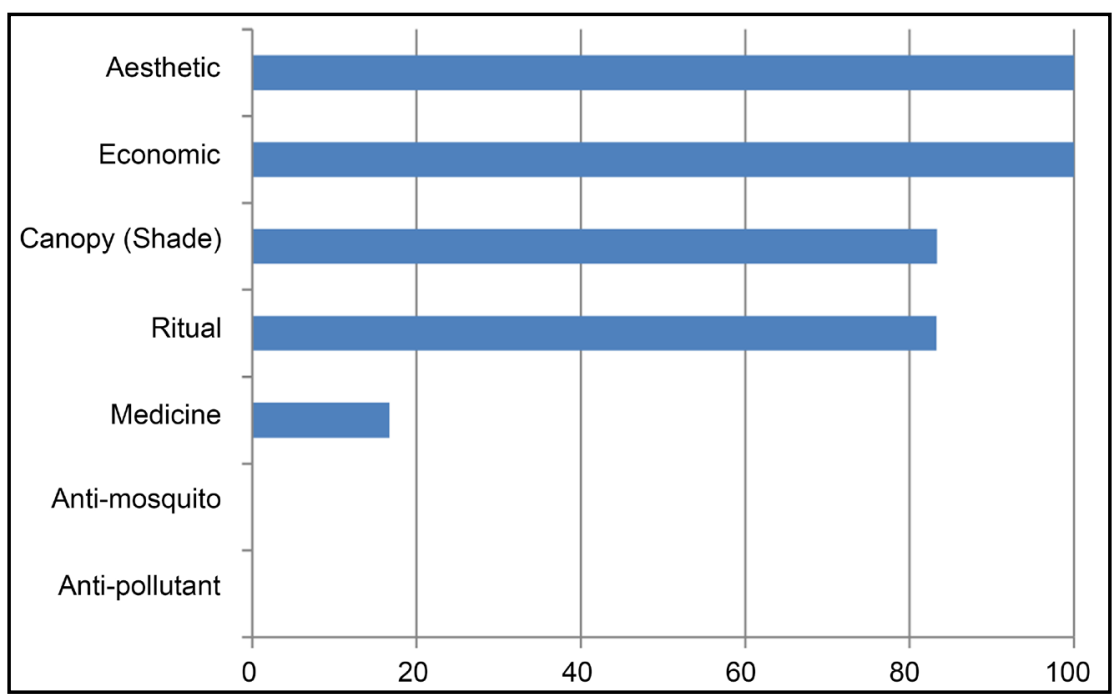

Figure 5. Percentage of the functions provided by the plants in sample 4 .

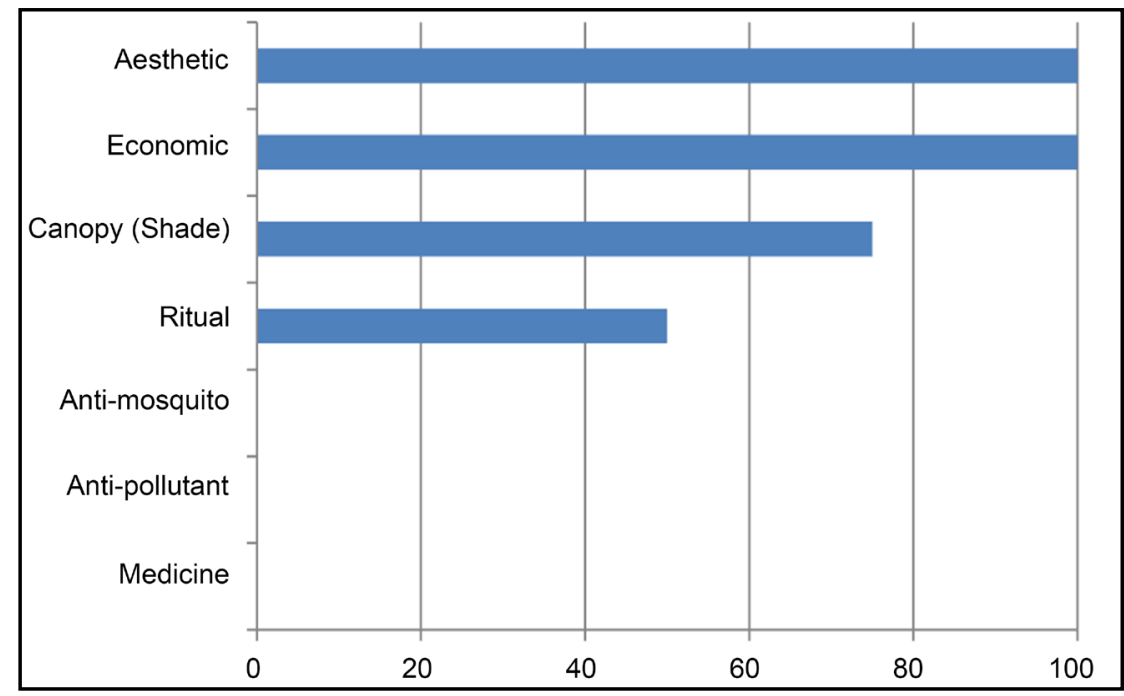

Figure 6. Percentage of the functions provided by the plants in sample 5. 
provided function with the average of $83.6 \%$.

Second, in terms of the total number of different species, sample 1 has the most number of species. 51 species are identified in sample 1 , followed by 26 species in sample 2, 11 species in sample 3, 6 species in sample 4, and 4 species in sample 5 (Table 1). As for the width of telajakan, sample 1 is the narrowest with $85 \mathrm{~cm}$; the average width of sample $2-5$ is much wider with $272.3 \mathrm{~cm}$ (Table 1).

Third, when comparing sample 1 (in Village $\mathrm{X}$ ) with sample 2 - 5 (in Village C), we find that: 1) sample 1 has by far the most number of species (most diverse); 2) (soil erosion) protection function exists only in sample $1 ; 3$ ) in sample 2 - 5, there are more species with economic function; and 4) there are not as many species with anti-mosquito function in sample $2-5$ on average as species in sample 1 (Figures 2-6).

Fourth, more weeds were observed in sample 1 than in sample $2-5$ with almost no weeds. Sample 2 - 5 are very well-maintained, evident in the existence of lolly-pop bonsai branches (Figure 7) with the ground weeded and swept by the owners and the neighbourhood clean-up group. The appearance of sample 1 is shown in Figure 11 and sample 2 - 5 in Figure 7 and Figure 13.

\section{Discussion}

\subsection{Transformation of Telajakan Space Itself}

As Denpasar undergoes rapid urbanization, telajakan is often paved over to give way to more front space for the property owner and to ease maintenance. It is also minimized or destroyed as the owner builds a more "western" style house. Based on our field observation, when an owner operates a shop, telajakan is paved over to provide 1) more frontal shop space and 2) temporary parking space for customers who come by cars and motorcycles. Even when telajakan

Table 1. Telajakan width and the number of species in each sample.

\begin{tabular}{rccccc}
\hline & Sample 1 & Sample 2 & Sample 3 & Sample 4 & Sample 5 \\
\hline Width (cm) & 85 & 300 & 227 & 278 & 284 \\
Num. of Spp. & 51 & 26 & 11 & 6 & 4 \\
\hline
\end{tabular}

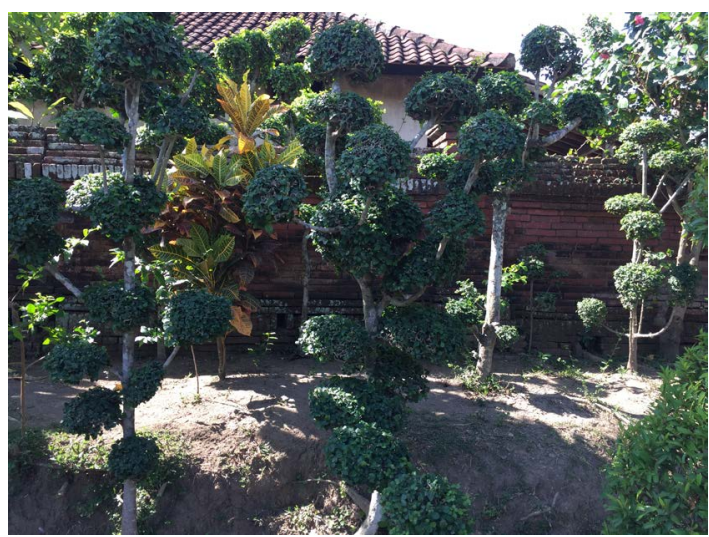

Figure 7. Bonsai trees in telajakan. 
remains as part of a housing compound, it is sometimes paved with concrete for easier maintenance (Figure 8). Telajakan also gives way to a more inner (completely) private space inside the wall.

\subsection{Changes with Regards to the Plantings in Telajakan}

\subsubsection{Functions}

In the past, the species planted were used mostly for ritual purposes. The planted species provided plant and flower materials for Balinese daily rituals (offering to the gods) (Figure 9). However, in the present, ritual function is not the most important function needed by telajakan owners. The results show that aesthetics is by far the most provided function by the plantings, followed by economic function. The fact that aesthetic function is provided by almost $100 \%$ of the

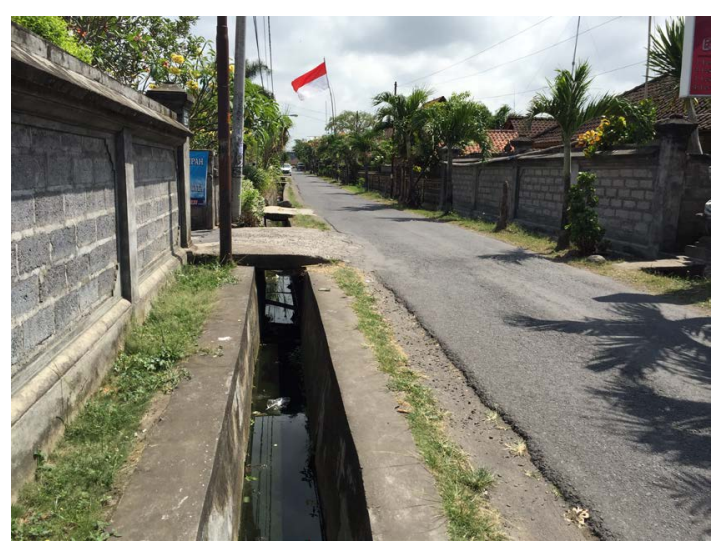

Figure 8. Diminishing and deteriorating telajakan.

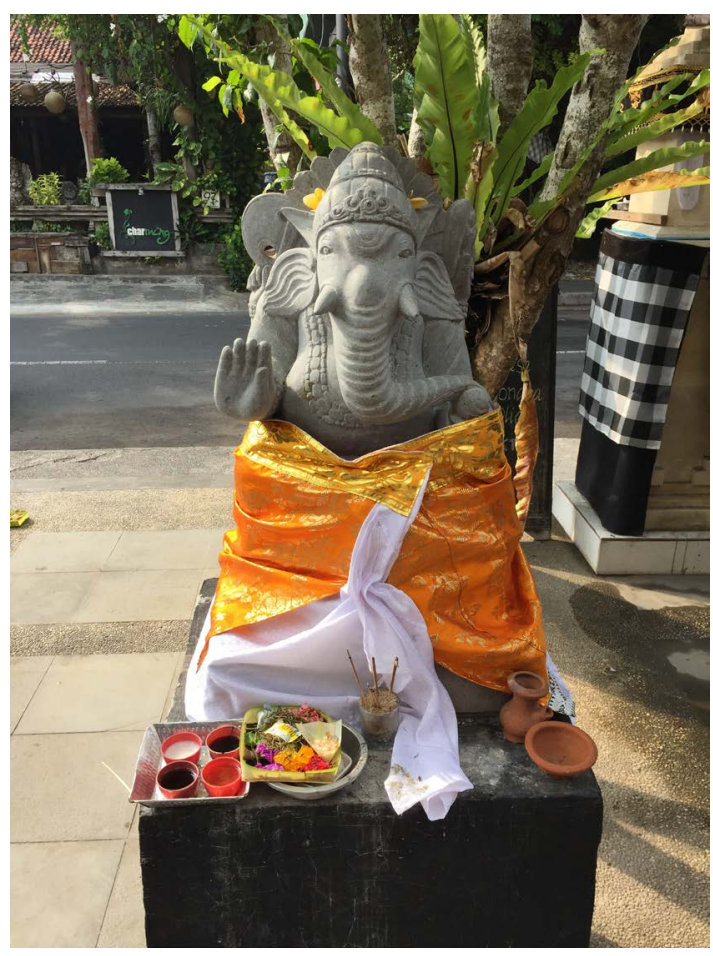

Figure 9. Plant and flower materials used for the offering. 
planted species underscores its importance to the telajakan owners (i.e., housing compound owners). The observation that there were almost no weeds in sample 2 - 5 corroborates the value of a "neat look" of telajakan as a social status and the increased importance placed on the aesthetics. What matters most to telajakan owners nowadays is the appearance of telajakan and the economic value of most of the species. For example, in Village C, where samples 2 - 5 were taken, planting of pudak (Dracaena angustifolia) is preferred as a cash plant (Figure 10). According to the interviews, the owners can sell Dracaena angustifolia after it grows to a certain size.

\subsubsection{Comparison between Sample 1 and Sample 2 - 5}

Based on the expert opinion, sample 1 is considered to be a more traditional type of telajakan than sample $2-5$. This is because: 1) not only does sample 1 have the most diverse plant species but also it has the most number of functions (Table 1); 2) there is a variety of height and kinds from tall trees to short shrubs; and 3) there are some weeds in sample 1. Even though some may criticize the existence of weeds as poor maintenance, these weeds add to the diversity of species with a complex vertical structure (Figure 11).

When comparing sample 1 with sample 2 - 5, only in sample 1 protection function is observed; in sample $2-5$ there are more species with economic

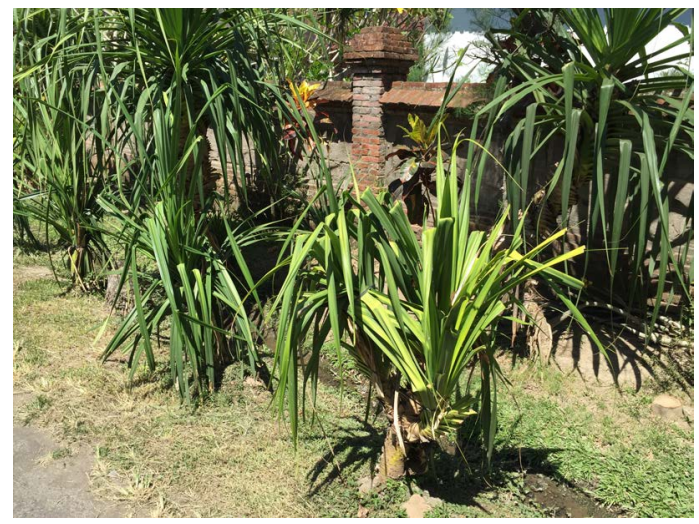

Figure 10. Pudak planted as a cash plant.

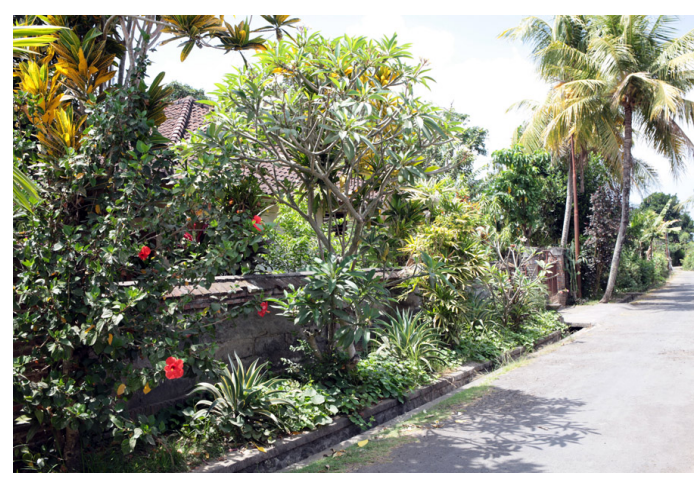

Figure 11. Sample 1 more traditional style telajakan having a complex vertical structure (Photo: Kosuke Hishiyama). 
function. The effect of protection function on stormwater control will be discussed later. Sample 2 - 5 has fewer numbers of different species (less diverse) with higher percentage of the species offering economic function. The example of Dracaena angustifolia as a preferred cash plant in the neighbourhood is explained above. What is interesting in terms of function is that even though this village had won telajakan competition (public hygiene and remove mosquito habitats) many times in the past (Figure 12), sample 2 - 5 does not necessarily contain as many species with anti-mosquito function as sample 1.

Having won the telajakan competition many times in the past may have to do with the width of telajakan: average telajakan width of sample 2 - 5 is three times wider than that of sample 1 (Table 1). The wide telajakan accommodates enough space for showcasing bonsai trees and other species with beautiful forms and color (Figure 13). The space also allows for growing cash plants such as Dracaena angustifolia and Amaryllis sp.

\subsection{Overall Discussion on the Changes of Telajakan}

Traditionally telajakan has multiple functions such as provision of plant and flower materials for Balinese daily rituals, regulation of stormwater from the property, and offering semi-public space for street vendors and neighbours.

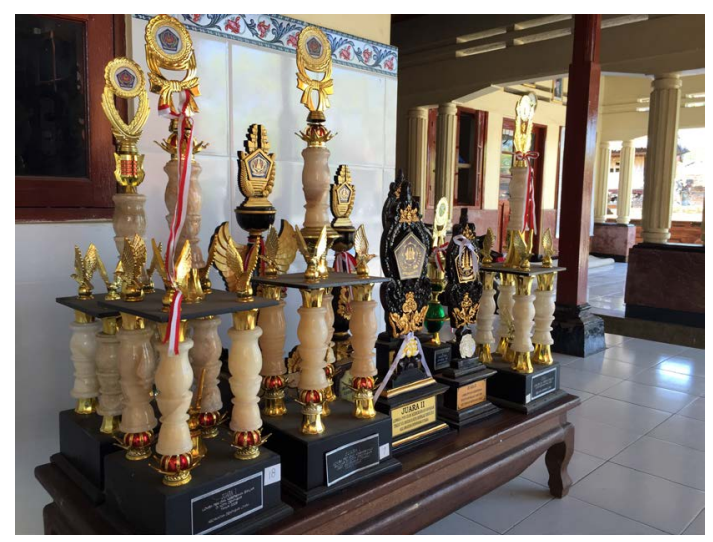

Figure 12. Telajakan competition trophies.

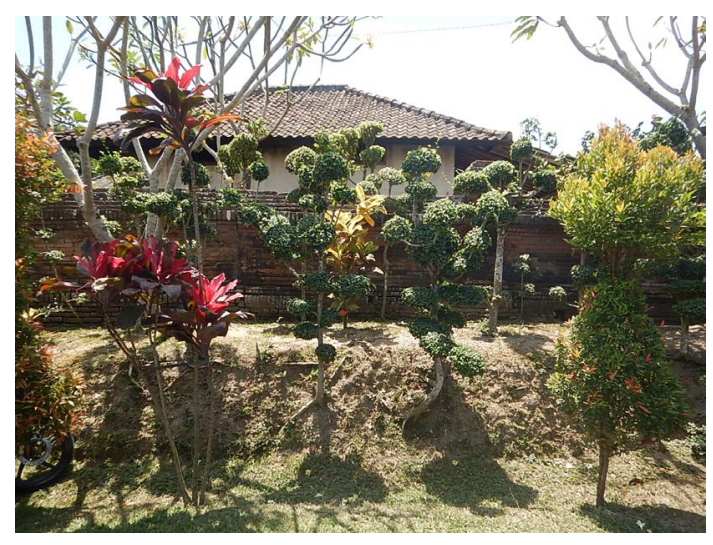

Figure 13. More contemporary style telajakan with plantings focused on aesthetic function. 
However, the results show that only a couple of functions are strongly favoured, focusing on aesthetic and economic aspects, and that the semi-public nature of telajakan is being lost. Although not all changes are negative, the loss and shrinkage of telajakan certainly affects the custom and daily lives of ordinary people.

As we have discussed so far, the current situation that telajakan space itself is diminishing and paved over negatively affects its stormwater regulation function. In the past, more rainfall was absorbed by the soil and the plantings in telajakan; some was evapotranspired by the plants. The finding that only in the more traditional telajakan, there is a species with (soil erosion) protection function also hints that telajakan in the past had more rainwater absorption and erosion control capacity partly due to the kinds of species planted. Numerous telajakan in Denpasar City helped reduce runoff water and the chance of urban flooding. Now with the reduction and loss of telajakan, urban flooding has become more common, affecting the lives of city residents.

The loss and marginalization of telajakan also affect how people interact on the streets. In the past, conversation sprang up and more interaction was born as neighbours and passers-by stop to buy small bites and drinks from street vendors parked in the telajakan space. More eyes on the streets may have helped reduce crime in the neighbourhood. Nowadays, people come by cars and motorcycles, buy what they need, and leave in a hurry. There is not as much interaction among the shop owner, customers, and the neighbors even when telajakan space is provided for temporary parking and frontal shop space.

Telajakan's loss and its changing functions are feared to lead to the loss of traditional southern Balinese culture and tradition. However, not all changes are negative. For example, as seen in sample 2 - 5, local government's telajakan competition gives new meaning to telajakan to showcase owners' financial status and neighborhood's pride through aesthetically pleasing, neat, and clean streets, which also reduce mosquito habitats, reducing the spread of dengue fever and increasing public hygiene. Promoting telajakan through this kind of competition may hint a new way of telajakan conservation in the modern context.

\section{Conclusion}

Since telajakan is deeply rooted in traditional Balinese architecture, its loss, degradation, and marginalization necessarily lead to the loss of Balinese culture and identity. However, our research finds that new meaning is given to telajakan's functions such as neighbourhood beautification and exhibition of the owner's pride and financial status in the modern context. Thus, when making policy recommendations to conserve telajakan in the changing urban fabric, the conservation of traditional rituals and culture of Bali needs to be balanced against the changing needs of telajakan for its use.

\section{Acknowledgements}

The authors express sincere gratitude toward Dr. Ngakan Ketut Acwin Dwijendra of STD Bali for his expert advice on the research. The authors would also 
like to thank Mr. Freddy Hendrawan of STD Bali and Mr. Adi M. of Udayana University for their assistance of the field investigation. The authors would also like to thank three anonymous reviewers for their comments, which helped to greatly improve the paper. This research is funded by The Obayashi Foundation. The authors are grateful for its support.

\section{References}

[1] Yudantini, N.M. (2012) Natah and Telajakan: The Role and Identity in Indigenous Villages. Proceedings of International Seminar on Place Making and Identity 2012, Jakarta, Indonesia, 26-27 September 2012, 179-187.

[2] Putra, I.D.G.A.D., Lozanovska, M. and Fuller, R. (2013) The Transformation of the Traditional Balinese House for Tourist Facilities: Managing a Home-Based Enterprise and Maintaining an Architectural Identity. Proceedings of the 2013 Asia-Pacific Management and Business Application International Conference on Management and Business Science, Denpasar, 5-6 September 2013, 53-67.

[3] Brata, I.B. (2014) Commodification of Telajakan at Ubud Village, Gianyar, Bali. E-Journal of Cultural Studies, 7, 1-6.

http://ojs.unud.ac.id/index.php/ecs/article/view/8417/6280

[4] Yudantini, N.M. and Jones, D. (2015) The Role of Traditional Regulation in the Indigenous Villages for Conservation of Village Pattern. Proceedings of 21 st International Sustainable Development Research Society Conference, International Sustainable Development Research Society, Geelong, Victoria, 10-12 July 2015, 1-10.

[5] Dwijendra, N.K.A. (2008) Arsitektur Rumah Tradisional Bali. Kerjasama Bali Media Adhikarsa [dengan]. Udayana University Press, Denpasar.

[6] Keng, H. (1978) Orders and Families of Malayan Seed Plants. Singapore University Press, Singapore.

[7] Periplus Editions (1999) 500 Popular Tropical Plants. Periplus Editions (HK) Ltd., Hong Kong.

Submit or recommend next manuscript to SCIRP and we will provide best service for you:

Accepting pre-submission inquiries through Email, Facebook, LinkedIn, Twitter, etc. A wide selection of journals (inclusive of 9 subjects, more than 200 journals)

Providing 24-hour high-quality service

User-friendly online submission system

Fair and swift peer-review system

Efficient typesetting and proofreading procedure

Display of the result of downloads and visits, as well as the number of cited articles

Maximum dissemination of your research work

Submit your manuscript at: http://papersubmission.scirp.org/

Or contact oje@scirp.org 